\title{
Introduction of Stevia rebaudiana Bertoni in in vitro culture
}

Asadova S.Sh. ${ }^{1,2}$

${ }^{1}$ Institute of Molecular Biology \& Biotechnology of the National Academy of Sciences of Azerbaijan; Baku, Azerbaijan; ${ }^{2}$ Research Institute of Crop Husbandry of the Ministry of Agriculture of Azerbaijan; Baku, Azerbaijan

E-mail: biotexnoloqaz@mail.ru

Key message. A cell culture obtained from explants of adult plants and aseptic seedlings of the Stevia rebaudiana Bertoni variety with different levels of ploidy, characterized by high speed, proliferation and ability to morphogenesis.

Keywords: Stevia rebaudiana, explant, callusogenesis, morphogenesis

Stevia rebaudiana Bertoni is known as a natural sweetener. However, studies conducted in recent years have shown its therapeutic effect in the treatment of certain metabolic diseases [1, 2, 3]. For the successful introduction of stevia into the territory of Azerbaijan, first of all, it is necessary to study its biomorphological features, determine the optimums and the limits of its tolerance to the soil and climatic conditions of various regions of the country. The aim of this work was to study the characteristics of Stevia rebaudiana Bertoni plants at the body (in vivo) and at the cellular (in vitro) levels. The seeds of 4 Russian varieties with different levels of ploidy, such as Detskoselskaya, Medovaya travka, Mechta, Uslada, as well as cuttings of a sample brought from Turkey were used as research materials. Monthly developmental phases as well as phases of mass flowering and seed formation were observed at plants grown in nursery conditions. Stem parts, leaf blades and petioles of leaves of different ages, primordial leaves, and seeds were isolated as explants in plants for cultivation in vitro. At the same time, aseptic seedlings were obtained and their tissues were also introduced into the culture. The explants were transferred to different variants of the medium for callusogenesis, where Murashige-Skoog (MS) and Gamborg (B B $_{5}$ composed the basis. Callusogenesis was induced by adding various concentrations of 2,4- dichlorophenoxyacetic acid, $\alpha$-naphthylacetic acid and kinetin to the medium. 6-benzylaminopurine was used to induce morphogenesis. The differentiation of explants began on the $5-7^{\text {th }}$ day of passaging. After proliferation, callus had a heterogeneous structure. In most cases, they consisted of a dense cluster of greenish-colored cells, but there were areas of more weakly linked yellow and white cells. The callus proliferation rate was higher while using 2,4-D and kinetin at a concentration of $5 \mathrm{mg} / \mathrm{L}$. When sufficient mass was reached, the callus was transplanted onto the regeneration medium. The morphogenesis of the cell culture of Stevia rebaudiana Bertoni depending on the degree of ploidy is being discussed.

\section{Введение медовой травы Stevia rebaudiana Bertoni в культуру in vitro} Асадова С.Ш..$^{1,2}$

${ }^{1}$ Институт молекулярной биологии и биотехнологий Национальной академии наук Азербайджана, Баку, Азербайджан; ${ }^{2}$ Научно-исследовательский институт земледелия, Баку, Азербайджан

Аннотация. Клеточная культура, полученная из эксплантов взросльх растений и асептических проростков сортов
Stevia rebaudiana Bertoni c разным уровнем плоидности, отличалась по структуре, скорости пролиферации и способности кморфогенезу.

Ключевые слова: Stevia rebaudiana, эксплант, каллусогенез, морфогенез

Stevia rebaudiana Bertoni известна как природный сахарозаменитель. Однако проведенные в последние годы исследования показали ее терапевтический эффект при лечении некоторых заболеваний метаболического характера [1,2,3]. Для осуществления успешной интрадукции стевии на территорию Азербайджана прежде всего необходимо изучение ее биоморфологических особенностей, определение оптимумов и пределов ее толерантности к почвенно-климатическим условиям различных регионов республики. Целью данной работы являлось изучение характеристики растений Stevia rebaudiana Bertoni на организменном (in vivo) и на клеточном (in vitro) уровнях. Материалом исследования служили семена 4-х российских сортов с разным уровнем плоидности: Детскосельская, Медовая травка, Мечта, Услада, и черенки образца, привезенного из Турции. Для выращенных в условиях закрытого грунта растений отмечены фазы развития по месяцам, вплоть до фаз массового цветения и семенообразования. Для культивирования в условиях in vitro у растений в качестве эксплантов были изолированы части стебля, листовые пластинки и черешки листьев разного возраста, примордиальные листья, семена. Одновременно были получены асептические проростки, ткани которых также были введены в культуру. Экспланты переносили на различные варианты среды для каллусогенеза, основу которых составляли среды Мурасиге-Скуга $(\mathrm{M}-\mathrm{S})$ и Гамборга $\left(\mathrm{B}_{5}\right)$. Каллусогенез индуцировали добавлением в среду разных концентраций 2,4-дихлорфеноксиулсусной кислоты, $\alpha$-нафтилуксусной кислоты и кинетина. Для индукции морфогенеза использовали 6-бензиламинопурин. Дедифференциация экслантов начиналась на 5-7 день пассирования. После пролиферации каллусы имели неоднородную структуру. В большинстве своем они состояли из плотного скопления клеток зеленоватого оттенка, но имелись участки с более слабо сцепленными клетками желтого и белого цветов. Скорость пролиферации каллусов была выше при использовании 2,4-Д и кинетина в концентрации 5 мг/л. При достижении достаточной массы каллусы пересаживались на среду для регенерации. Обсуждается особенность морфогенеза клеточной культуры Stevia rebaudiana Bertoni в зависимости от степени плоидности.

1. Gregersen S., P.B. Jeppesen, J.J. Holst, K. Hermansen Antihyperglycemic effects of stevioside in type 2 diabetic subjects. Metabolism, 53 (2004), pp. 73-76.

2. Brahmachari G., Mandal L.C., Rajeev Roy, S. Mondal, A.K. Brahmachari. Stevioside and related compounds - molecules of pharmaceutical promise: a critical overview. Arch. Pharm. - Chem. Life Sci., 344 (2011), pp. 5-19.

3. Amin K., Ozgen S., Selamoglu Z. Stevia Rebaudiana: A Potential Boon for Human Health. SM J. Med. Plant Stud. 2017; 1(1): 1005-1010. 